\title{
Redesign of Facility Layout at Pelangi Advertising Printing Using the SLP Method
}

\author{
Syafirman Pramija ${ }^{a^{*}}$ and Meipen ${ }^{a^{* *}}$ \\ a) Mechanical Engineering Student, Universitas Riau, Indonesia \\ *Corresponding author: Syafriman.Pramija2948@gmail.com; Meipen2805@gmail.com
}

\section{Paper History}

Received: 10-May-2021

Received in revised form: 05-June-2021

Accepted: 30-July-2021

\begin{abstract}
This paper aim is to investigate the work system for printing service and redesign facility layout improvement. A case study was conducted in small company namely Pelangi Advertising Printing. The Systematic Layout Planning (SLP) was adopted in this paper. The input data and activities in the SLP process are as follows: material flow, activity relationship, string diagrams, area requirement, area available, space relationship diagrams, modification consideration and practical limitations. The results of this study indicated the application of SLP in case study company can increase in facility layout efficiency from $96.7 \%$ to $98.5 \%$. The redesign facility layout result was more effective than the initial layout.
\end{abstract}

\section{KEY WORDS: Facility layout, Systematic Layout Planning, Printing}

\subsection{INTRODUCTION}

Basically printing is an industry that is intended to produce text and images in large quantities. Printing is even considered as one of the primary human needs. Various kinds of daily needs are produced from the printing industry, such as books, brochures, packaging boxes, banners and others. Printing business in Indonesia itself has grown rapidly, starting from small to large business. Competition is also common in the business world, especially businesses in the field of printing services. For this reason, a good strategy is needed to face competition in this business world. One of strategy is to layout design for optimizing the arrangement of operating facilities, which can be adopted the SLP (Systematic Layout Planning) method.
The selection of the SLP method is varying in accordance with the characteristics of the company that requires adjustments. This approach has detailed procedures for setting up layout so that it is possible to bring up more than one solution alternative, which can be chosen the best alternative to solve layout problems [1]. The facility layout can be defined as the procedure for setting up factory facilities to support the smooth production process [2]. This arrangement is useful for the area of placing machines or other production support facilities, smooth movement of material, storage of materials both temporary and permanent, worker personnel and so on $[3,4]$.

Continuous development of facility layout preparation procedures develops along with the complexity of the problems faced. The problems are often faced to prepare the layout of new facility, the rearrangement and improvement of the existing layout for practical problems [5,6]. The objectives to be achieved by preparing the layout of the facility are generally increasing work productivity, and optimizing the use of existing facilities such as work areas, machines and labor [7-9]. The SLP study has been done by some researchers such as [1012]. In general, researchers it performs a re-layout or preliminary design of the facility layout, machines and departments in a factory or services facilities. Their researches were the SLP method implementation for layout design location of several industries. This approach has detailed procedures for setting up layout so that it is possible to bring up more than one solution alternative, which can be chosen the best alternative to solve layout problems.

The SLP method is able to increase effectiveness and efficiency by reducing displacement and material handling costs in the factory facility design [14]. The steps of SLP method [15]: data collection is used as the first step for layout planning based on ongoing and planned production activities. After that, a planning activity relationship diagram is made using a combination of material flow analysis and activity relationship analysis. The next step is to plan a space relationship diagram. This space relationship diagram pays attention to the need for the necessary facilities and also the availability of the existing area. Taking into account the necessary modifications and practical limitations, an alternative layout can be designed and evaluated.

The current distance for moving work activities in Pelangi 
Advertising Printing is not optimal and it is necessary to redesign the layout to reduce the distance. Through the existing problems, this paper aim is to investigate the work system for Pelangi printing services, make layout improvements and observe the performance of each layout quantitatively. The limitation applied in this study is not changing the operating capacity of each printing service process, not changing the available area; quantitative performance was calculated by the distance from one facility to another. This research has scope to improve efficiency and effectiveness facility layout in case study company.

\subsection{METHODOLOGY}

This paper was adopted the qualitative and quantitative methods. The stages methods were used in this paper:

1. Data collection. This stage was collected the data, which deal with the problem of effectiveness. It measured the area of the pelangi advertising printing facility area.

2. Observation. This stage collected the data to find out the steps and processes in service activity process at pelang advertising printing. The collection data such as by measuring distances between departments and measuring operating time in each process.

3. Interview. This stage conducted the interviews with employees of pelangi advertising printing. This aimed to find out information about the operating process for each activity in producing services.

The data in this study was used in the form of primary data and secondary data. The primary data was obtained through direct observation and interview. The primary data were: layout of production facilities; type of service; the flow of the activity process produces services.

The secondary data was the information that has been made available by the company or other parties deemed competent. These data include: company profile; land area and company building; the resulting product data; production quantity data; production process; data on the type and number of machines used; material handling tools; material flow in the production process.

The data was collected in this study in the form of quantitative data and qualitative data. The explanation of the data was as follows:

a. Quantitative data was gathered as follows:

- The processing time of each operation

- Number of machines used in printing

- Number of employees

- The amount of output produced

- Distance between departments.

b. Qualitative data was as follows:

- Type of product produced

- What services were sold

- Overview of rainbow advertising printing

- The process stage of each printing activity from start to finish.

\section{Data Processing}

The data processing was carried out using the SLP (Systematic Layout Planning) method. The steps of SLP were as following:

- The obtaining data was processed to be developed by

adjusting the method used.

- Compile information about the sequence of processes and the flow of each printing activity.

- Then compile an assembly chart or work map that describes the process steps.

- Create an OPC (Operation Process Map) that describes the flow pattern or process steps experienced from the beginning to the end of the process.

- Identify the number of machines and equipment used.

- Make Activity Relationship Diagram Chart and Space Relationship Diagram or activity between each part that illustrates the importance of proximity between equipment.

- Create a layout design based on the Systematic Layout study.

- Conclusions and suggestions, the advice was given as information for consideration for pelangi advertising printing.

\subsection{RESULT AND DISCUSSION}

\subsection{Input Analysis}

Pelangi Printing Advertising is a small business engaged in the field of marketing services with a store area of $18 \mathrm{~m}^{2}$. In every day, the company runs the printer activities of 9 types of printing services. Pelangi Advertising Printing employs 2 employees with work duration of 10 hours/day. And on average they sell approximately 50 services from various types of services. The initial layout of the Pelangi advertising printing is shown in Figure 1.

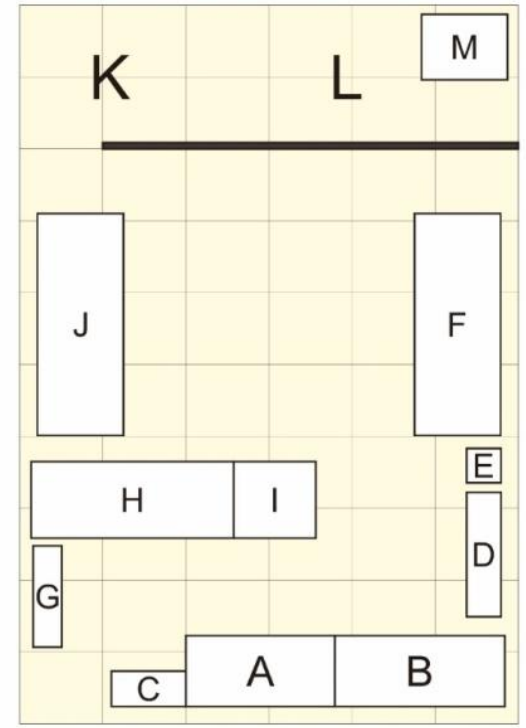

Figure 1: Initial layout in the case study company

The description:

$\mathrm{A}=$ Storefront 1

$\mathrm{B}=$ Storefront 2

$\mathrm{C}=$ Stamp Storefront

$\mathrm{D}=$ Invitation Showcase

$\mathrm{E}=$ Laminating Machine

$\mathrm{F}=$ Workbench 2

$$
\begin{aligned}
& \mathrm{G}=\text { Showcase } \\
& \mathrm{H}=\text { Workbench } 1 \\
& \mathrm{I}=\text { Copier } \\
& \mathrm{J}=\text { Printer Desk } \\
& \mathrm{K}=\text { Rest Room } \\
& \mathrm{L}=\text { Warehouse } \\
& \mathrm{M}=\text { Toilet }
\end{aligned}
$$


In the initial layout, the average activity carried out was constrained, because the location of the photocopy machine was in the middle. So that the employee went further on an activity that must used several facilities that pass through the photocopy machine. From the results of data collection in the form of observations can be depicted in Table 1. It can be seen in Table 1, the types of services were obtained along with the process time, sequences process order and distances.

Table 1: the distance, time processed and the process order for types of services

\begin{tabular}{|c|c|c|c|c|}
\hline No & $\begin{array}{l}\text { Type of } \\
\text { services }\end{array}$ & $\begin{array}{c}\text { Time } \\
\text { (second) }\end{array}$ & $\begin{array}{c}\text { Sequences } \\
\text { Process } \\
\text { Order }\end{array}$ & Distance \\
\hline 1 & Photocopy & 8.54 & B - I - A & $1.5 \mathrm{~m}$ \\
\hline 2 & Laminating & 9.47 & $\mathrm{~B}-\mathrm{E}-\mathrm{A}$ & $3.0 \mathrm{~m}$ \\
\hline 3 & Invitation Print & 17.46 & $\begin{array}{l}B-D-H \\
-J-F-A\end{array}$ & $8.5 \mathrm{~m}$ \\
\hline 4 & Print & 13.38 & $\mathrm{~B}-\mathrm{J}-\mathrm{A}$ & $5.0 \mathrm{~m}$ \\
\hline 5 & Design & 15.20 & $\mathrm{~B}-\mathrm{H}-\mathrm{A}$ & $3.0 \mathrm{~m}$ \\
\hline 6 & Name card & 14.85 & $\begin{array}{c}\mathrm{B}-\mathrm{H}-\mathrm{J}- \\
\mathrm{A}\end{array}$ & $5.0 \mathrm{~m}$ \\
\hline 7 & Brochure & 14.75 & $\begin{array}{c}\mathrm{B}-\mathrm{H}-\mathrm{J}- \\
\mathrm{A}\end{array}$ & $5.0 \mathrm{~m}$ \\
\hline 8 & Stamp & 9.20 & $\mathrm{C}-\mathrm{F}-\mathrm{A}$ & $4.5 \mathrm{~m}$ \\
\hline 9 & MUG & 15.24 & $\begin{array}{c}\mathrm{B}-\mathrm{H}-\mathrm{J}- \\
\mathrm{F}-\mathrm{A}\end{array}$ & $8.0 \mathrm{~m}$ \\
\hline
\end{tabular}

\subsection{Efficiency}

It was known the productive time for a day of 10 hours. Then the initial layout results were obtained the number of cycle time, work station and efficiency facility layout in the company case study.

Productivity time $=10$ hours $/$ day $(600$ minutes $)$ with an average of selling 50 services from various types of printing services. The total time for all types of services from facility to facility was 116.09 seconds.

Cycle time $=\frac{600 \text { minute }}{50}=12$ unit.

Work station $=\frac{116.09 \text { second }}{12 \text { unit }}=9.6=10$

Efficiency $=\frac{116.09 \text { second }}{10 \times 12} \times 100 \%=96.7 \%$

\subsection{Activity Relation Chart (ARC)}

The Activity Relationship Chart (ARC) method or the degree of linkage is a technique for planning the relationship between work stations based on the degree of relationship between the activities stated in the assessment by using letters and numbers indicating the reason for the code. The Activity Relation Chart (ARC) diagram is depicted in Figure 2.

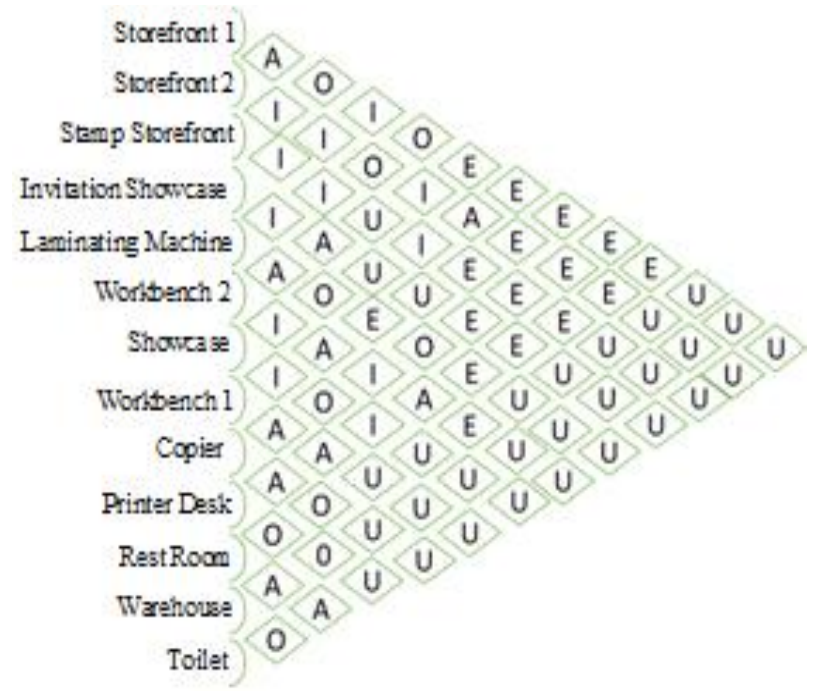

Figure 2: Activity Relation Chart (ARC)

Table 2: Relationship characteristics

\begin{tabular}{cc}
\hline Characteristics & Activity Relationship \\
\hline A & Very important \\
E & Urgent \\
I & Enough \\
O & Not important \\
U & Very unimportant \\
\hline
\end{tabular}

\subsection{Results Analysis}

From the analysis and calculations that have been carried out, the facility layout of the result can be seen in Figure 3 .

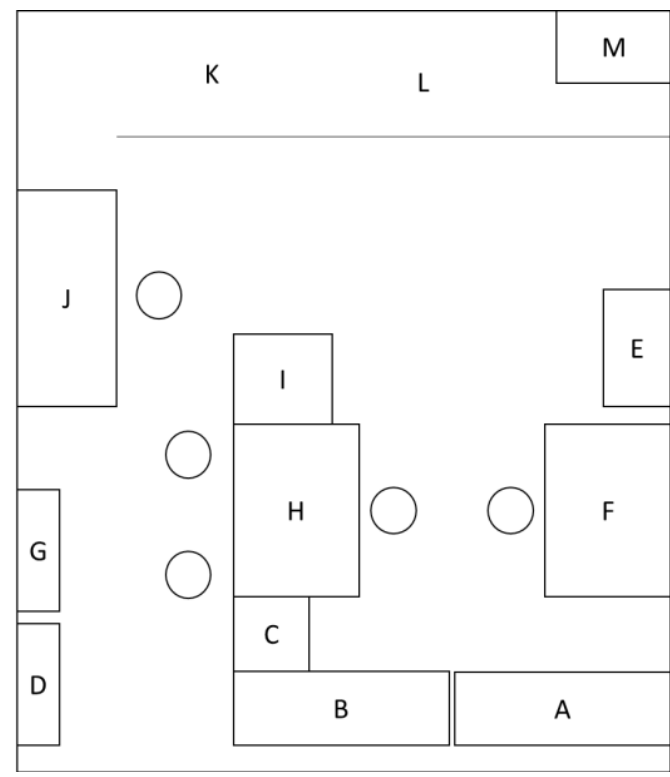

Figure 2: Result layout in case study company 
With description:

$\mathrm{A}=$ Storefront 1

$\mathrm{B}=$ Storefront 2

$\mathrm{C}=$ Stamp Storefront

$\mathrm{D}=$ Invitation Showcase

$\mathrm{E}=$ Laminating Machine

$\mathrm{F}=$ Workbench 2

$\mathrm{G}=$ Showcase

$\mathrm{H}=$ Workbench 1

$\mathrm{I}=$ Copier

$\mathrm{J}=$ Printer Desk

$\mathrm{K}=$ Rest Room

$\mathrm{L}=$ Warehouse

$\mathrm{M}=$ Toilet

Table 3: the distance, time processed and the process order for types of services (result layout)

\begin{tabular}{ccccc}
\hline No & $\begin{array}{c}\text { Type } \\
\text { service }\end{array}$ & $\begin{array}{c}\text { Time } \\
\text { (second) }\end{array}$ & $\begin{array}{c}\text { Sequences } \\
\text { Process } \\
\text { Order }\end{array}$ & Distance \\
\hline 1 & Photocopy & 6.45 & B - I - A & $1.3 \mathrm{~m}$ \\
2 & Laminating & 7.37 & B - E - A & $2.5 \mathrm{~m}$ \\
3 & Invitation Print & 15.56 & B - D - H & $6.5 \mathrm{~m}$ \\
& & & $-\mathrm{J}-\mathrm{F}-\mathrm{A}$ \\
4 & Print & 7.27 & $\mathrm{~B}-\mathrm{J}-\mathrm{A}$ & $5 \mathrm{~m}$ \\
5 & Design & 7.10 & $\mathrm{~B}-\mathrm{H}-\mathrm{A}$ & $2 \mathrm{~m}$ \\
6 & Name card & 8.88 & $\mathrm{~B}-\mathrm{H}-\mathrm{J}-$ & $4.5 \mathrm{~m}$ \\
& & & $\mathrm{~A}$ & \\
7 & Brochure & 8.89 & $\mathrm{~B}-\mathrm{H}-\mathrm{J}-$ & $4 \mathrm{~m}$ \\
& & & $\mathrm{~A}$ & \\
8 & Stamp & 7.88 & $\mathrm{C}-\mathrm{F}-\mathrm{A}$ & $3.5 \mathrm{~m}$ \\
9 & MUG & 14.22 & $\mathrm{~B}-\mathrm{H}-\mathrm{J}-$ & $6.5 \mathrm{~m}$ \\
& & & $\mathrm{~F}-\mathrm{A}$ &
\end{tabular}

It was known that the productive time for a day of 10 hours / day. Then the redesign layout in the company case study was obtained the number of cycle time, amount of the work station and the efficiency of facility layout result.

Productivity time $=10$ hours $/$ day $(600$ minutes $)$ with an average of selling 50 services from various types of printing services. The total amount of time for all types of services from facilities to other facilities in the results layout was 75.62 seconds.

Cycle time $=\frac{600 \text { minutes }}{50}=12$ unit.

Work station $=\frac{75.62 \text { second }}{12 \text { unit }}=6.3=6$

Efficiency $=\frac{75.62 \text { second }}{6 \times 12} \times 100 \%=98.5 \%$

\subsection{CONCLUSION}

The results of data analysis on distance, time and number of sequences process order comparing the current layout with the new alternative layout. It has shown that a change in the facility layout location with the SLP method is quite significant in improving the distance and time of moving goods. From the results of the analysis that has been carried out using ARC (Activity Relation Chart) and by calculating the initial layout efficiency, the layout efficiency is $96.7 \%$. After being redesigned using the SLP method, an efficiency is obtained $98.5 \%$. The facility layout in the case study company result is more effective and efficient than the initial facility layout.

\section{REFERENCES}

[1] Meyers, F.E. (1992). Plant Layout and Material Handling. New Jersey: Prentice Hall.

[2] Tak, C.S and Yadav, L. (2012). Improvement in layout design using SLP of a small size manufacturing unit: A case study, IOSR Journal of Engineering (IOSRJEN), 2(10), 1-7.

[3] Santos, L., Gohr, C., and Urio, L.C.S. (2014) Systematic layout planning in small enterprises: An application in an automotive battery plant, Espacios, 35 .

[4] Naqvi, S.A.A., Fahad, M., Atir, M. (2016). Productivity improvement of a manufacturing facility using systematic layout planning, Cogent Engineering, 3(1).

[5] Maina, E. (2018). Improvement of facility layout using systematic layout planning, IOSR Journal of Engineering, 8, 33-43.

[6] San, G.S. dan Sugiarto, D.W. (2000). Analisa tata letak pabrik untuk meminimalisasi material handling pada pabrik koper, Jurnal Teknik Mesin, 2(1).

[7] Hossain, M.R., Kamruzzaman, R. and Talapatra, S. (2014). Increasing productivity through facility layout improvement using systematic layout planning pattern theory, Global Journal of Engineering Education, 14(7).

[8] Wanniarachchi, W.N.C., Gopura, R.A.R.C. and Punchihewa, H.K.G. (2016). Development of a layout model suitable for the food processing industry, Journal of Industrial Engineering, ID 2796806, 1-8. https://doi.org/10.1155/2016/2796806.

[9] Daf, S.P. and Zanwar, D.R. (2013). Analysis and improvement in plant layout for effective production in manufacturing industries, International Journal of Technology, 3(1), 19-28.

[10] Jain, A.K., Khare, V. and Mishra, P. (2013) Facility planning and associated problems: a survey, Innovative Systems Design and Engineering, 4(6), 1-8,

[11] Bagaskara, B., Gozali, L., Widodo, L. and Daywin, F.J. (2020). Comparison study of facility planning and layouts studies, IOP Conf. Series: Materials Science and Engineering, 852, doi:10.1088/1757$899 X / 852 / 1 / 012105$.

[12] Arief, D.S., Susilawati, A., Simaskot, J., Badri, M. and Dalil, M. (2017). Management of motorcycle workshops of SMEs scale based on information system, Journal of Ocean, Mechanical and Aerospace Science and Engineering-, 47, 9-16. 
[13] Islam, M., Rashed and Anam, C.A. (2017). Productivity improvement through the application of systematic layout planning technique, Review of General Management, 25, 38-53.

[14] Choir, M., Arief, D.S. and Siska, M. (2017). Desain ulang tata letak fasilitas produksi menggunakan metode systematic layout planning pada pabrik kelapa sawit sungai pagar, JOM Fakultas Teknik Unri, 4(1), 1-6.

[15] Sunardi, Esya, J. and Santoso, B. (2020). Redesign of the production facility layout by using systematic layout planning method at cahaya bintang mas company Surabaya, Journal of Physics: Conference Series. 1569. Doi,10.1088/1742-6596/1569/3/032007. 